\title{
Effects of $\beta$-hydroxy $\beta$-methylbutryate (HMB) supplementation on testosterone and cortisol concentration of athletes: A systematic review and meta-analysis of randomized controlled trials
}

\author{
Liu Gang ${ }^{1}$ \\ ${ }^{1}$ Hunan University of Technology
}

October 8, 2020

\begin{abstract}
Background: $\beta$-hydroxy $\beta$-methylbutryate (HMB) is a metabolite of leucine amino acid and it has several ergogenic benefits. Previous studies also showed that it may affect beneficially the testosterone and cortisol concentration in athletes. Due to the contradiction results between studies, we aimed to conduct this meta-analysis to assess the HMB supplementation effect on testosterone and cortisol in trained athletes. Methods: Scopus, Medline and Google scholar were systematically searched up to August 2020. The Cochrane Collaboration tool for evaluating the risk of bias was applied for assessing the studies quality. Random effects model, weighted mean difference (WMD), and 95\% confidence interval (CI) were used for estimating the overall effect. Between-study heterogeneity was evaluated applying the chi-squared and I2 statistic. Results: Seven articles were included in the meta-analysis. Although, the meta-analysis generally showed that HMB consumption did not have any effect on the cortisol and testosterone concentration $(\mathrm{P}>0.05)$, but subgroup analysis based on the exercise type, showed a significant decrease in the cortisol concentration in resistance training exercises (WMD $=-3.30 ; 95 \%$ CI: $-5.50,-1.10 ; \mathrm{P}=0.003$ ) and a significant increase in the testosterone concentration in aerobic and anaerobic combined sports $(\mathrm{WMD}=1.56 ; 95 \% \mathrm{CI}$ : $0.07,3.05 ; \mathrm{P}=0.040)$. Conclusion: The results indicate that HMB supplementation in athletes can reduce the concentration of cortisol in resistance exercises and increase the concentration of testosterone in aerobic and anaerobic combined exercises. Nevertheless, more studies are required to confirm these results.
\end{abstract}

\section{Introduction}

In recent years, an enormous growth of interest has been placed on nutritional supplements for enhancing training-induced adaptations. This interest has been motivated by this theory that nutritional supplements may improve performance by increasing anabolic and decreasing catabolic effects, thereby improving body composition and decreasing exercise-induced muscle damage (1-3).

One potential nutrient is the leucine metabolite $\beta$-hydroxy $\beta$-methylbutryate (HMB)supplementation, that it may result in several ergogenic advantages, including anti-catabolic (4), anabolic (5) and lipolytic impacts (6). HMB a leucine and 2-ketoisocaproic acid metabolite has been suggested to enhance recovery and improve skeletal muscles during high-volume and high-intensity exercises (7-10). It has been reported that HMB increased strength (11), power (12) and lean body mass $(5,6)$ through muscle breakdown inhibition during exercise and protein synthesis increase after exercise. Recent data suggested that the advantages of HMB supplementation may be attributed to the some mechanisms including; 1) upregulation of IGFI (Insulin-like growth factor 1) expression in skeletal muscle, 2) stimulating synthesis of protein via the mammalian/mechanistic target of rapamycin complex 1 (mTOR), 3) membrane stabilization of muscle cells, 4) decreasing proteolysis by inhibition of the ubiquitin-proteasome pathway $(8,13)$.

Previous studies also have found that supplementation with HMB resulted in beneficial effects on performance by increasing anabolic hormones, including IGF-1, growth hormone and testosterone and decreasing catabolic 
stress hormones such as cortisol $(7,14)$. HMB also may increase androgen concentration through increasing cholesterol, drawing on this hypothesis that, HMB is metabolized to $\beta$-hydroxy $\beta$-methylglutaryl CoA (HMG-CoA) which is a main source of cholesterol synthesis and precursor of androgens such as testosterone (15).

While several studies have supported the HMB beneficial effect in physical activity and clinical condition, some other studies have shown conflicting results about the HMB supplementation effect on testosterone and cortisol concentration in athletes (16-18). For example, Durkalec-Michalski et al. reported an increase in testosterone after 12 weeks supplementation with HMB (3x1g HMB/ day) in 84 highly-trained males (19). However, in another study, testosterone and cortisol did not change in 28 male trained athletes after 6 weeks HMB supplementation (3g/day) (20).

From our point of view, no systematic review and meta-analysis has been conducted over the HMB supplementation effect on testosterone and cortisol in trained athletes. Moreover, due to the contradiction results between studies and common HMB consumption as an ergogenic aid, particularly among athletes, we aimed to conduct this systematic review and meta-analysis to assess the effects of HMB supplementation on testosterone and cortisol in trained athletes.

\section{Methods}

\subsection{Search Strategy}

This systematic review and meta-analysis was reported according to the guidelines of Preferred Reporting Items for Systematic Reviews and Meta-Analyses (PRISMA) (21). A computerized search was coducted from inception to August 2020 using various databases including PubMed, ISI Web of Science, Scopus, and supplementary Google Scholar search. The following terms and their combinations of MeSH and non-MeSH terms were applied, including: "beta hydroxy beta methylbutyrate", "hydroxy methyl butyrate", "HMB", "exercise," "sport supplements", "endocrine response" "cortisol", and "testosterone". Reference lists of all studies were checked for further eligible articles identification.

\subsection{Eligibility Criteria:}

Studies were selected by applying the following Population-Intervention-Comparator-Outcomes-Study design (PICOS) criteria (21): 1) healthy subjects received oral HMB supplementation, as a nutritional strategy before and after exercise; 2) original randomized-controlled trial researches and 3) reporting at least one outcome measure of hormones (cortisol and testosterone). Studies were not conducted by using multiple supplementations, (HMB in conjunction with other supplement like creatine (20), arginine, lysine (22) and adenosine monophosphate (23)). There were restrictions on the performed post-exercise and studies that assessed the acute effect of HMB on the hormonal response $(24,25)$.

\subsection{Selection strategy:}

After computerized search, titles and received papers abstracts were screened by the search strategy. Two authors (LG and M.M) selected articles based on the inclusion criteria independently. Articles including eligibility criteria in the title and abstract screening were elected to be checked by full manuscript. Parallel clinical trials were elected by applying a control group or crossover design in the systematic review and meta-analysis. All classified trials were retrieved by either of the authors. According to the data within the full information, we used a form to elect the studies eligible for inclusion in the meta-analysis. Contradictions between the authors were solved by consensus or third researcher.

\subsection{Data extraction:}

M.M and LG extracted following needed information: first author's name, year and publication country, design of studies, gender and age of subjects, HMB dose and sample size, duration of intervention, and training status. Also, we extracted mean and standard deviation (SD) of plasma hormones' status (cortisol and testosterone) at baseline and after the intervention. 


\subsection{Study quality:}

Given that trial inclusion with a high risk of bias may distort the outcomes of a meta-analysis $(26,27)$, the Cochrane Collaboration tool was used for evaluating the risk of bias. The following items were evaluated: randomization sequence generation; allocation concealment; blinding of participants, personnel, investigator, and assessor; attrition rates; and companies financial interest. These items were given high, unclear, or low risk of bias rating. A study was categorized as having low, medium, or high-risk according to the key areas of allocation concealment, reporting of attrition rates, and participants and assessor (high $=$ all 4 factors rated high, medium $=2$ or 3 factors rated high or unclear, and low $=$ all key areas rated low).

2.6. Analyses and measures of treatment effect:

For each trial, mean differences and standard deviation were calculated for continuous variables. The differences of mean changes in cortisol and testosterone concentration and their correspondence SD were extracted as the effect size. In trials that the standard error (SE) measure was reported, SE was converted to SD applying this formula: $\mathrm{SD}=\mathrm{SE} \times[?] \mathrm{n}$ ( $\mathrm{n}=$ number of subjects in each group). Between-study heterogeneity was assessed using the chi-squared $\left(\chi^{2}\right)$ test and quantified applying the $\mathrm{I}^{2}$ statistic, which shows the total variation percentage across studies that is ascribable to heterogeneity rather than to chance. Significant heterogeneity was defined with a P-value of $<0.05$.

The random effects model was applied to calculate the weighted mean differences (WMDs) with 95\% confidence intervals (CIs) for estimating the overall effect. To evaluate whether the outcomes could have been altered by a single study distinctly, a sensitivity analysis was performed (28). Also, subgroup analysis was conducted, based on the sports type (resistance training or aerobic and anaerobic combined training) and duration of studies (over six weeks and 6 weeks or lower). Publication bias was evaluated by Egger's regression asymmetry test and Begg's rank correlation test. Funnel plots also depicted the effect sizes against their corresponding standard errors. Statistical analyses were conducted applying STATA 11.2 software (StataCorp, College Station, Texas, USA).

\section{Results}

3.1. Search outcomes and overview of included studies

Our initial search led to 184 relevant studies. After removing duplications, a wide range of screening of the titles and abstracts, the careful assessment was performed on 142 related articles. Of these, 11 articles remained after considering the inclusion and exclusion criteria for the eligibility. Eventually, 7 articles, including, 8 effect sizes, which studied a total of 235 participants aged $16.1-24.9$ years, were identified in the current systematic review and meta-analysis.Figure 1 represents the selection process and reasons for excluding the studies. The data in Table 1 illustrates the main characteristics of the articles in our systematic review and meta-analysis.

In brief, the studies (by 235 participants) were published between 2001 and 2017. The duration of these RCTs ranged between 1.5 to 12 weeks. 2 studies used a randomized crossover design $(19,29)$, one of them was also single blind (30) and the other studies had the design of double-blind. Two studies were conducted in Poland (19, 29), 1 in the United States (30), 1 in Iran (31), 2 in Australia (20,32) and 1 in Israel (7). The effect of exercise on testosterone and cortisol concentration was examined in 7 studies $(7,19,20,29-32)$; and 8 effect sizes were extracted from these studies for testosterone and cortisol concentration. The total number of subjects who completed the studies in inclusion criteria was 121 subjects in the intervention and 107 in the placebo groups. The dose of HMB supplementation was $3 \mathrm{~g} /$ day in all studies.

\subsection{Risk of bias}

The quality of the studies is presented in Table $\mathbf{2}$. Briefly, random sequencing generation was unclear in 3 studies $(20,30)$. Participants and outcome blinding and incomplete outcome data were high and unclear risk of bias in only two studies, respectively $(20,32)$. And then ranked as low risk of bias for 5 studies $(7$, 
19, 29-31), medium risk of bias for 1 study (32), and high risk of bias for 1 study (20). Most of studies had a low risk of bias for selective reporting and other sources of bias except for one study (20).

3.3. Findings from the meta-analysis

3.3.1. Effects of HMB supplementation on serum cortisol concentration

Overall, HMB consumption had no significant effect on cortisol concentration: WMD $=-1.35 \mu \mathrm{g} / \mathrm{dl} ; 95 \% \mathrm{CI}$ : $-2.70,0.002 ; \mathrm{P}=0.050$. There was no significant heterogeneity among the studies (Cochran's $\mathrm{Q}$ test $=14.05$, $\mathrm{P}=0.050, \mathrm{I}^{2}=50.2 \%$ ). Subgroup analyses of different types of exercise showed that cortisol concentration significantly reduced after resistance exercises $(\mathrm{WMD}=-3.30 \mu \mathrm{g} / \mathrm{dl} ; 95 \% \mathrm{CI}:-5.50,-1.10 ; \mathrm{P}=0.003)$, whereas it had not significant effect on cortisol concentration in aerobic and anaerobic combined activities (WMD $=$ $-0.16 ; 95 \%$ CI: $-1.16,0.84 ; \mathrm{P}=0.753)$. The results of subgroup analysis are shown in Table 3 and the forest plot is shown inFigure 2 .

\subsubsection{Effects of HMB supplementation on testosterone concentration}

As outlined in Table 4 , our preliminary analysis indicated that HMB consumption did not significantly improve serum testosterone concentration $(\mathrm{WMD}=0.75 \mathrm{nmol} / \mathrm{L} ; 95 \% \mathrm{CI}:-0.09,1.58 ; \mathrm{P}=0.079)$. Also, no significant heterogeneity was observed among studies (Cochran's $\mathrm{Q}$ test $=3.33, \mathrm{P}=0.853, \mathrm{I}^{2}=0.00 \%$ ). Subgroup analysis was conducted to check as to how the effect of HMB supplementation on serum testosterone is different according to type of exercise activities (Figure 3 ) or duration of the interventions (Figure 4 ). This analysis revealed that the pooled effect of HMB supplementation on testosterone concentration was influenced by the duration of the supplementation ( $<6$ weeks versus [?]6 weeks), in which a significant increase in testosterone concentration was found in studies that lasted longer than 6 weeks $(\mathrm{WMD}=1.60$ nmol/L; 95\% CI: 0.08, 3.12; $\mathrm{P}=0.039)$. Also, subgroup analysis based on the type of exercise training indicated that the increasing effect of $\mathrm{HMB}$ supplementation on serum testosterone is significant in aerobic and anaerobic combined activities ( $\mathrm{WMD}=1.60 \mathrm{nmol} / \mathrm{L} ; 95 \% \mathrm{CI}: 0.08,3.12 ; \mathrm{P}=0.039)$. Subgroup analysis didn't show any significant effect of HMB supplementation on testosterone concentration in studies lasting lower than six weeks $(\mathrm{WMD}=0.38 ; 95 \% \mathrm{CI}:-0.62,1.38 ; \mathrm{P}=0.455)$ or on resistance training exercise $(\mathrm{WMD}=$ $0.38 \mathrm{nmol} / \mathrm{L} ; 95 \% \mathrm{CI}:-0.63,1.38 ; \mathrm{P}=0.464)$.

\subsubsection{Sensitivity analysis and publication bias}

Sensitivity analysis showed that the omission of any of the studies from the meta-analysis, create no change in the outcomes of the meta-analysis on testosterone concentration whereas, the results on cortisol concentration were sensitive to omitting 3 studies $(7,29,30)$. Funnel plots for cortisol and testosterone were visually symmetrical, and the results of Egger's test did not determine any evidence of publication bias in studies that examine the effect of HMB consumption on cortisol (Egger's test, $\mathrm{P}=0.337$ ) and on testosterone (Egger's test, $\mathrm{P}=0.140$ ).

\section{Discussion}

The efficacy of HMB has not been distinctly established regarding hormonal responses; thus, this systematic review and meta-analysis provided comprehension into the potential benefits conferred by HMB supplementation to help athletes to make aware decisions on its usage and impact. In this systematic review and meta-analysis of 7 studies (235 participants), we found that HMB consumption led to a significant decrease in cortisol and increase in testosterone concentrations after resistance exercises and aerobic and anaerobic combined activities, respectively. Several probable mechanisms have been suggested for the beneficial effects of HMB supplementation on testosterone and cortisol concentration in athletes.

Our results support those of past investigations showing that amino acid consumption may play a role in reducing exercise-induced increases in cortisol (33). Cortisol, is a catabolic hormone and basic glucocorticoid form in humans, secreted from the adrenal cortex in response to psychological and physical stress (34). During cortisol elevates in exercise, impacts of this hormone happen after exercise within the early recovery. Elevation in plasma cortisol concentration, within the physiological range in short-term, motivates proteolysis 
and augments plasma leucine utilization and concentration (35). The study of Knitter (36) showed that HMB operated as an anti-catabolic agent rather than an anabolic agent. The mechanism for this reaction is not exactly obvious. Some studies support the anti-catabolic hypothesis of HMB expressed by reductions in the muscle damage indices such as creatine phosphokinase and lactate dehydrogenase $(15,37)$ and subsequent lower cortisol levels. The major characteristics of skeletal muscle damage without cell necrosis is the muscle fibers disruption, exclusively the basal lamina sheath. Regarding mechanical stimuli, especially in resistance exercise, it is known that it can boost micro damage in muscle fibers imposed by contractions or overload and, depending on the volume, duration and intensity of training, the degree and severity of damage and discomfort may be combined over time $(38,39)$. As such, HMB can affect muscle damage and cortisol levels more efficiently after resistance exercise. However, more studies should be conducted to reveal physiological and molecular mechanisms by which muscle damage markers were decreased after HMB supplementation.

Moreover, cortisol shows an anticipatory reaction to exercise and physical activity (40), and Kraemer et al. previously suggested that this reaction was reduced using a herbal supplement with specifically designed (41). Because amino acids supplementation increases the circulating amino acid concentrations (42), possibly less cortisol was needed for gluconeogenesis before exercise to break down proteins into amino acids.

Reduced cortisol at rest enhances the anabolic-to-catabolic hormone ratio, that in theory, would increase testosterone chronically and muscle tissue protein balance (12). Also, the primitive destination of HMB is a conversion to HMG-CoA in the cytosol of liver and muscle, thus HMB is a precursor of cholesterol (43, 44), and HMB supplementation leads to an increase in synthesis of cholesterol and may act as a structural component of cell membranes (45). Given that damaged muscle cells after exercise (46) may lose their ability to make sufficient HMG-CoA for the synthesis of cholesterol, HMB supplement for more than 6 weeks may be a suitable source of HMG-CoA to synthesize testosterone $(15,47)$. The increment in testosterone concentration seems to be linked with an increase in the endogenous cholesterol that is a substrate in the steroidogenesis process. Additionally, our results in regard to the HMB and aerobic and anaerobic exercise effects on changes in the testosterone response propose that acute ingestion does not increase the testosterone response to exercise. Townsend et al. study carried out 3 exercise protocols throughout the 12 weeks to assay the supplementation acute response. At supplementation of weeks 6 and 9, the response of testosterone was increased in the intervention group (24). Therefore, chronic supplementation of HMB may lead to a more pronounced response of testosterone. The increase of testosterone concentration could be considered as a beneficial result and demonstrate a better anabolic status in athletes, which plays a key roles in training adaptation and recovery in well-trained athletes (48).

To the best of our knowledge, this study is the first systematic review and meta-analysis that attempt to summarize the role of HMB supplementation on hormonal changes (cortisol and testosterone) in athletes. All included studies administered the same doses of HMB for intervention and all participants were male (except in one study (49)) that resulted in a decrement in heterogeneity. Moreover, the absence of heterogeneity among the included studies enhanced the power of our outcomes. However, some limitations should be mentioned. Considering the above items, it is not possible to evaluate the effect of the HMB consumption in female athletes and dose-response relationship between HMB supplementation and hormonal changes. Lack of information about data on frequency and intensity of exercise, genetic background, lifestyle factors and lack of complete baseline cortisol and testosterone data for subgroup analysis make overall interpretation of the results difficult. Eventually, the type of exercise was varied among the included studies, which could affect the reported outcomes.

In conclusion, the current systematic review and meta-analysis outcomes revealed that HMB supplementation may be linked with a decrease in cortisol concentration after resistance exercise. In contrast to cortisol, testosterone concentration significantly increased in aerobic and anaerobic combined training. more investigations are recommended with a variety of doses and exercises, longer time in periods and in both sexes in athletes.

\section{Conflicts of interest :}


None

References:

1. Ratamess NA. Emerging ergogenic aids for strength/power development. Dietary Supplementation in Sport and Exercise: Evidence, Safety and Ergogenic Benefits. 2019:190.

2. Fernández-Landa J, Calleja-González J, León-Guereño P, Caballero-García A, Córdova A, Mielgo-Ayuso J. Effect of the combination of creatine monohydrate plus HMB supplementation on sports performance, body composition, markers of muscle damage and hormone status: A systematic review. Nutrients. 2019;11(10):2528.

3. Naderi A, Earnest CP, Lowery RP, Wilson JM, Willems ME. Co-ingestion of nutritional ergogenic aids and high-intensity exercise performance. Sports Medicine. 2016;46(10):1407-18.

4. Knitter A, Panton L, Rathmacher J, Petersen A, Sharp R. Effects of $\beta$-hydroxy- $\beta$-methylbutyrate on muscle damage after a prolonged run. Journal of Applied Physiology. 2000;89(4):1340-4.

5. Jówko E, Ostaszewski P, Jank M, Sacharuk J, Zieniewicz A, Wilczak J, et al. Creatine and $\beta$-hydroxy$\beta$-methylbutyrate (HMB) additively increase lean body mass and muscle strength during a weight-training program. Nutrition. 2001;17(7-8):558-66.

6. Gallagher PM, Carrithers JA, Godard MP, Schulze KE, Trappe SW. $\beta$-hydroxy- $\beta$-methylbutyrate ingestion, part I: Effects on strength and fat free mass. Medicine \& Science in Sports \& Exercise. 2000;32(12):210915.

7. Portal S, Zadik Z, Rabinowitz J, Pilz-Burstein R, Adler-Portal D, Meckel Y, et al. The effect of HMB supplementation on body composition, fitness, hormonal and inflammatory mediators in elite adolescent volleyball players: a prospective randomized, double-blind, placebo-controlled study. European journal of applied physiology. 2011;111(9):2261-9.

8. Zanchi NE, Gerlinger-Romero F, Guimaraes-Ferreira L, de Siqueira Filho MA, Felitti V, Lira FS, et al. HMB supplementation: clinical and athletic performance-related effects and mechanisms of action. Amino acids. 2011;40(4):1015-25.

9. Wilson JM, Fitschen PJ, Campbell B, Wilson GJ, Zanchi N, Taylor L, et al. International Society of Sports Nutrition position stand: beta-hydroxy-beta-methylbutyrate (HMB). Journal of the International Society of Sports Nutrition. 2013;10(1):6.

10. Fernández-Landa J, Fernández-Lázaro D, Calleja-González J, Caballero-García A, Córdova Martínez A, León-Guereño P, et al. Effect of ten weeks of creatine monohydrate plus HMB supplementation on athletic performance tests in elite male endurance athletes. Nutrients. 2020;12(1):193.

11. Nissen S, Sharp R, Ray M, Rathmacher J, Rice D, Fuller Jr J, et al. Effect of leucine metabolite $\beta$ hydroxy- $\beta$-methylbutyrate on muscle metabolism during resistance-exercise training. Journal of Applied Physiology. 1996;81(5):2095-104.

12. Kraemer WJ, Hatfield DL, Volek JS, Fragala MS, Vingren JL, Anderson JM, et al. Effects of amino acids supplement on physiological adaptations to resistance training. Medicine \& Science in Sports \& Exercise. 2009;41(5):1111-21.

13. J Cruz-Jentoft A. Beta-hydroxy-beta-methyl butyrate (HMB): from experimental data to clinical evidence in sarcopenia. Current Protein and Peptide Science. 2018;19(7):668-72.

14. Asadi A, Arazi H, Suzuki K. Effects of p-Hydroxy-p-methylbutyrate-free Acid Supplementation on Strength, Power and Hormonal Adaptations Following Resistance Training. 2017.

15. Nissen SL, Abumrad NN. Nutritional role of the leucine metabolite $\beta$-hydroxy $\beta$-methylbutyrate (HMB). The Journal of Nutritional Biochemistry. 1997;8(6):300-11. 
16. Smith HJ, Wyke SM, Tisdale MJ. Mechanism of the attenuation of proteolysis-inducing factor stimulated protein degradation in muscle by $\beta$-hydroxy- $\beta$-methylbutyrate. Cancer research. 2004;64(23):8731-5.

17. Van Someren KA, Edwards AJ, Howatson G. Supplementation with $\beta$-hydroxy- $\beta$-methylbutyrate (HMB) and $\alpha$-ketoisocaproic acid (KIC) reduces signs and symptoms of exercise-induced muscle damage in man. International journal of sport nutrition and exercise metabolism. 2005;15(4):413-24.

18. Park B-S, Henning PC, Grant SC, Lee WJ, Lee S-R, Arjmandi BH, et al. HMB attenuates muscle loss during sustained energy deficit induced by calorie restriction and endurance exercise. Metabolism. 2013;62(12):1718-29.

19. Durkalec-Michalski K, Jeszka J, Podgorski T. The Effect of a 12-Week Beta-hydroxy-beta-methylbutyrate (HMB) Supplementation on Highly-Trained Combat Sports Athletes: A Randomised, Double-Blind, Placebo-Controlled Crossover Study. Nutrients. 2017;9(7).

20. Crowe MJ, O'Connor DM, Lukins JE. The effects of B-hydroxy-ß-methylbutyrate (HMB) and $\mathrm{HMB} /$ creatine supplementation on indices of health in highly trained athletes. International journal of sport nutrition and exercise metabolism. 2003;13(2):184-97.

21. Liberati A, Altman DG, Tetzlaff J, Mulrow C, Gøtzsche PC, Ioannidis JP, et al. The PRISMA statement for reporting systematic reviews and meta-analyses of studies that evaluate health care interventions: explanation and elaboration. Annals of internal medicine. 2009;151(4):W-65-W-94.

22. Flakoll P, Sharp R, Baier S, Levenhagen D, Carr C, Nissen S. Effect of $\beta$-hydroxy- $\beta$-methylbutyrate, arginine, and lysine supplementation on strength, functionality, body composition, and protein metabolism in elderly women. Nutrition. 2004;20(5):445-51.

23. Lowery RP, Joy JM, Rathmacher JA, Baier SM, Fuller Jr JC, Shelley MC, et al. Interaction of betahydroxy-beta-methylbutyrate free acid and adenosine triphosphate on muscle mass, strength, and power in resistance trained individuals. The Journal of Strength \& Conditioning Research. 2016;30(7):1843-54.

24. Townsend JR, Hoffman JR, Gonzalez AM, Jajtner AR, Boone CH, Robinson EH, et al. Effects of $\beta$-hydroxy- $\beta$-methylbutyrate free acid ingestion and resistance exercise on the acute endocrine response. International Journal of Endocrinology. 2015;2015.

25. Wilson JM, Lowery RP, Joy JM, Walters JA, Baier SM, Fuller JC, et al. $\beta$-Hydroxy- $\beta$-methylbutyrate free acid reduces markers of exercise-induced muscle damage and improves recovery in resistance-trained men. British Journal of Nutrition. 2013;110(3):538-44.

26. Higgins JP, Altman DG, Gøtzsche PC, Jüni P, Moher D, Oxman AD, et al. The Cochrane Collaboration's tool for assessing risk of bias in randomised trials. Bmj. 2011;343:d5928.

27. Liberati A, Altman DG, Tetzlaff J, Mulrow C, Gøtzsche PC, Ioannidis JP, et al. The PRISMA statement for reporting systematic reviews and meta-analyses of studies that evaluate health care interventions: explanation and elaboration. PLoS medicine. 2009;6(7):e1000100.

28. Tobias A. Assessing the influence of a single study in the meta-anyalysis estimate. Stata Technical Bulletin. 1999;8(47).

29. Durkalec-Michalski K, Jeszka J. The efficacy of a beta-hydroxy-beta-methylbutyrate supplementation on physical capacity, body composition and biochemical markers in elite rowers: a randomised, double-blind, placebo-controlled crossover study. J Int Soc Sports Nutr. 2015;12:31.

30. Hoffman JR, Cooper J, Wendell M, Im J, Kang J. Effects of beta-hydroxy beta-methylbutyrate on power performance and indices of muscle damage and stress during high-intensity training. Journal of strength and conditioning research. 2004;18(4):747-52.

31. Asadi A, Arazi H, Suzuki K. Effects of $\beta$-hydroxy- $\beta$-methylbutyrate-free acid supplementation on strength, power and hormonal adaptations following resistance training. Nutrients. 2017;9(12):1316. 
32. Slater G, Jenkins D, Logan P, Lee H, Vukovich M, Rathmacher JA, et al. $\beta$-hydroxy- $\beta$-methylbutyrate (HMB) supplementation does not affect changes in strength or body composition during resistance training in trained men. International journal of sport nutrition and exercise metabolism. 2001;11(3):384-96.

33. Sharp CP, Pearson DR. Amino acid supplements and recovery from high-intensity resistance training. The Journal of Strength \& Conditioning Research. 2010;24(4):1125-30.

34. Brownlee KK, Moore AW, Hackney AC. Relationship between circulating cortisol and testosterone: influence of physical exercise. Journal of sports science \& medicine. 2005;4(1):76.

35. Tinsley GM, Givan AH, Graybeal AJ, Villarreal MI, Cross AG. $\beta$-Hydroxy $\beta$-methylbutyrate free acid alters cortisol responses, but not myofibrillar proteolysis, during a 24-h fast. British Journal of Nutrition. 2018;119(5):517-26.

36. Knitter AE, Panton L, Rathmacher JA, Petersen A, Sharp R. Effects of beta-hydroxy-betamethylbutyrate on muscle damage after a prolonged run. Journal of applied physiology (Bethesda, Md : 1985). 2000;89(4):1340-4.

37. Rahimi MH, Mohammadi H, Eshaghi H, Askari G, Miraghajani M. The effects of beta-hydroxy-betamethylbutyrate supplementation on recovery following exercise-induced muscle damage: A systematic review and meta-analysis. Journal of the American College of Nutrition. 2018;37(7):640-9.

38. Nakhostin-Roohi B, Nasirvand Moradlou A, Mahmoodi Hamidabad S, Ghanivand B. The effect of curcumin supplementation on selected markers of delayed onset muscle soreness (DOMS). Annals of Applied Sport Science. 2016;4(2):25-31.

39. Jäger R, Purpura M, Kerksick CM. Eight weeks of a high dose of curcumin supplementation may attenuate performance decrements following muscle-damaging exercise. Nutrients. 2019;11(7):1692.

40. Suay F, Salvador A, González-Bono E, Sanchıs C, Martınez M, Martınez-Sanchis S, et al. Effects of competition and its outcome on serum testosterone, cortisol and prolactin. Psychoneuroendocrinology. 1999;24(5):551-66.

41. Kraemer WJ, French DN, Spiering BA, Volek JS, Sharman MJ, Ratamess NA, et al. Cortitrol supplementation reduces serum cortisol responses to physical stress. Metabolism. 2005;54(5):657-68.

42. Matsumoto K, Mizuno M, Mizuno T, Dilling-Hansen B, Lahoz A, Bertelsen V, et al. Branched-chain amino acids and arginine supplementation attenuates skeletal muscle proteolysis induced by moderate exercise in young individuals. International journal of sports medicine. 2007;28(06):531-8.

43. Rabinowitz JL. The Biosynthesis of Radioactive $\beta$-Hydroxyisovaleric Acid in Rat Liver1-3. Journal of the American Chemical Society. 1955;77(5):1295-6.

44. Rudney H. The biosynthesis of beta-hydroxy-beta-methylglutaric acid. The Journal of biological chemistry. 1957;227(1):363-77.

45. Nissen S, Sharp R, Ray M, Rathmacher JA, Rice D, Fuller JC, Jr., et al. Effect of leucine metabolite beta-hydroxy-beta-methylbutyrate on muscle metabolism during resistance-exercise training. Journal of applied physiology (Bethesda, Md : 1985). 1996;81(5):2095-104.

46. Evans WJ, Cannon JG. The metabolic effects of exercise-induced muscle damage. Exercise and sport sciences reviews. 1991;19:99-125.

47. Holecek M, Muthny T, Kovarik M, Sispera L. Effect of beta-hydroxy-beta-methylbutyrate (HMB) on protein metabolism in whole body and in selected tissues. Food and chemical toxicology. 2009;47(1):255-9.

48. Koundourakis NE, Margioris AN. The complex and bidirectional interaction between sex hormones and exercise performance in team sports with emphasis on soccer. Hormones. 2019:1-22. 
49. Portal S, Zadik Z, Rabinowitz J, Pilz-Burstein R, Adler-Portal D, Meckel Y, et al. The effect of HMB supplementation on body composition, fitness, hormonal and inflammatory mediators in elite adolescent volleyball players: a prospective randomized, double-blind, placebo-controlled study. Eur J Appl Physiol. 2011;111(9):2261-9.

\section{Figures:}

Figure 1- Flow diagram of the study selection process.

Figure 2- Forest plot representing the effect of HMB supplementation on the cortisol concentration. The analysis was done using a random-effects model, subgroup analysis performed based on the type of exercise activities.

Figure 3 - Forest plot representing the effect of HMB supplementation on the testosterone concentration. The analysis was done using a random-effects model, subgroup analysis performed based on the type of exercise activities.

Figure 4- Forest plot representing the effect of HMB supplementation on the testosterone concentration. The analysis was done using a random-effects model, subgroup analysis performed based on the duration of the interventions.

Figure 1. Flow diagram of the study selection process.

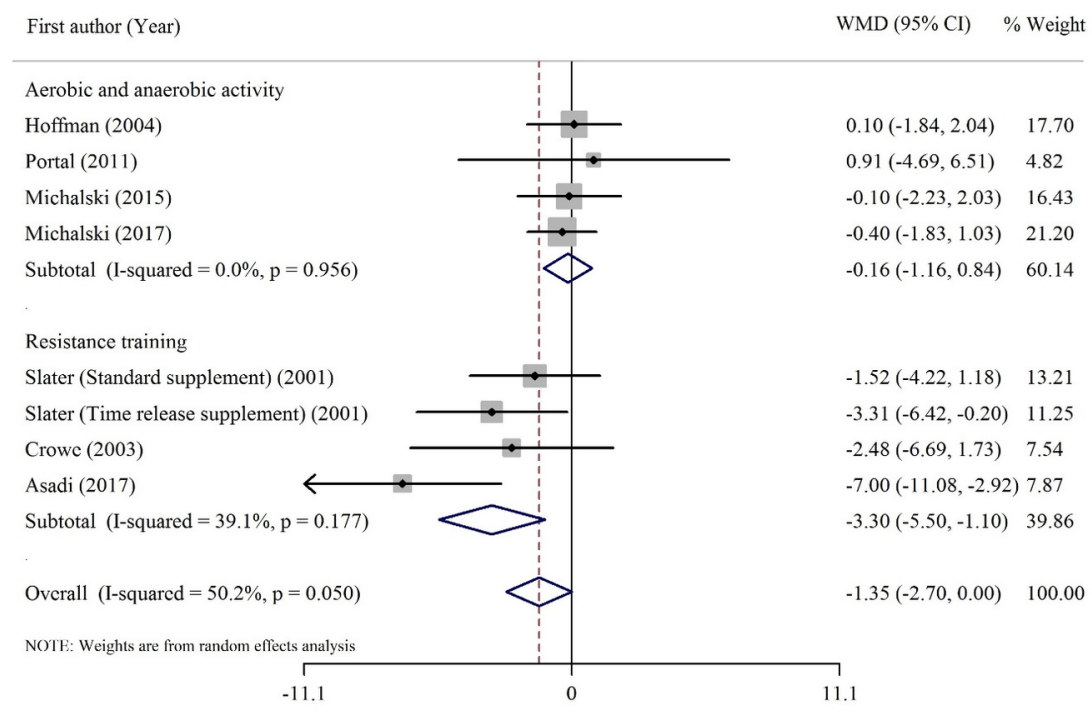

Figure 2- Forest plot representing the effect of HMB supplementation on the cortisol concentration. The analysis was done using a random-effects model, subgroup analysis performed based on the type of exercise activities. 


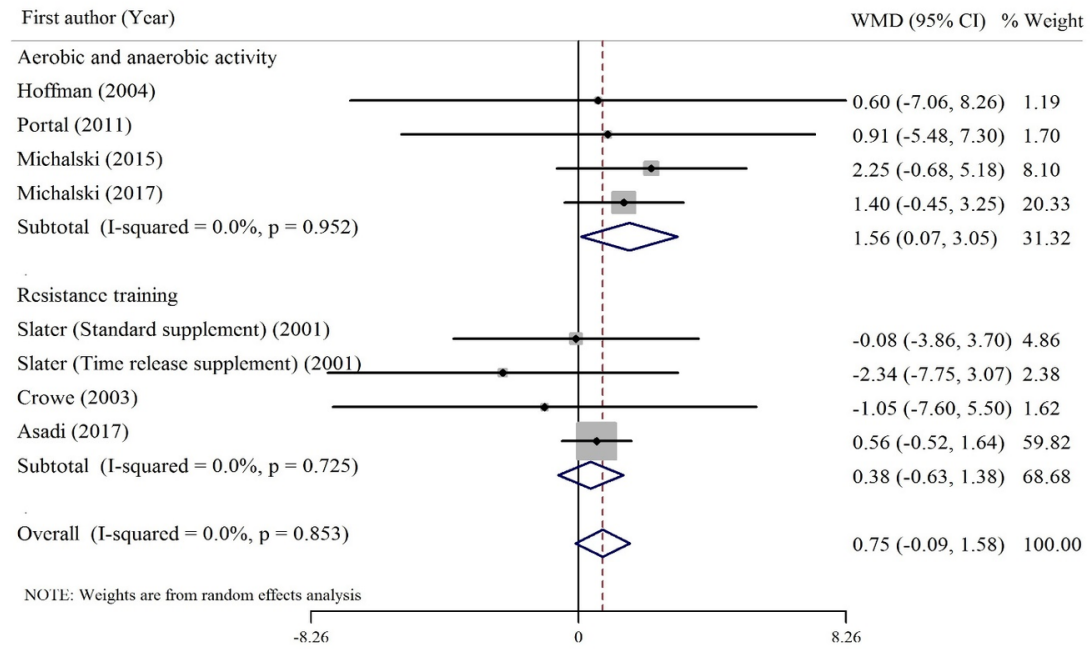

Figure 3 - Forest plot representing the effect of HMB supplementation on the testosterone concentration. The analysis was done using a random-effects model, subgroup analysis performed based on the type of exercise activities.

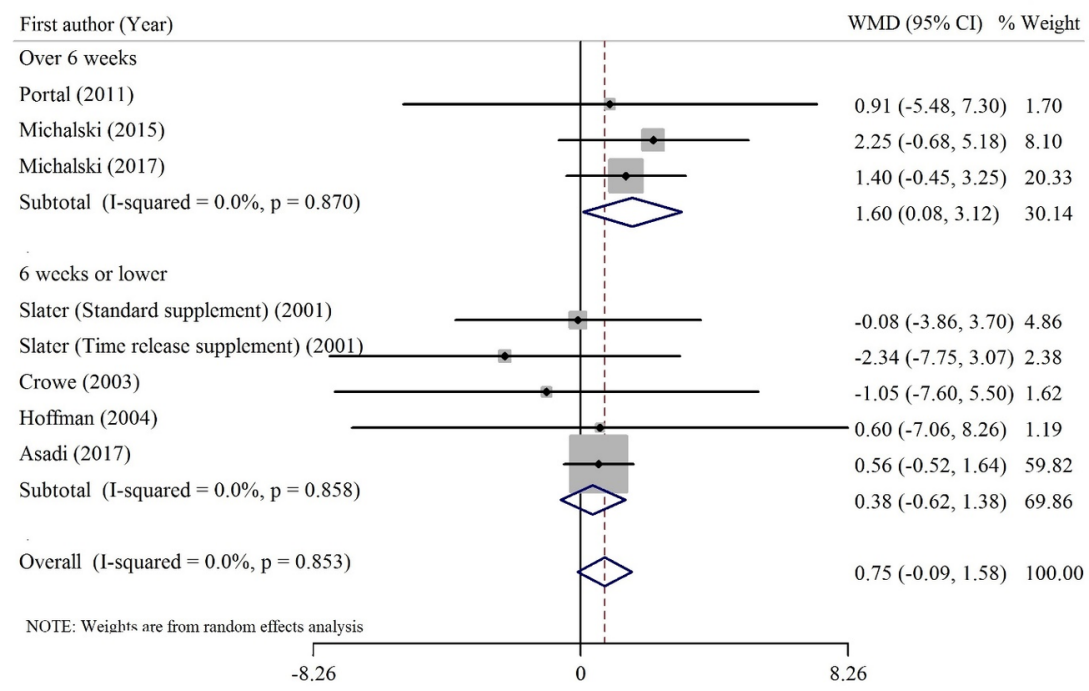

Figure 4- Forest plot representing the effect of HMB supplementation on the testosterone concentration. The analysis was done using a random-effects model, subgroup analysis performed based on the duration of the interventions.

Table 1. Characteristics of the Included Studies. 


\begin{tabular}{|c|c|c|c|c|c|c|c|c|c|}
\hline \multirow{2}{*}{$\begin{array}{l}\text { Evaluated } \\
\text { hormones }\end{array}$} & \multirow{2}{*}{$\begin{array}{l}\text { Sample } \\
\text { Size }\end{array}$} & \multirow{2}{*}{$\begin{array}{l}\text { Sample } \\
\text { Size }\end{array}$} & \multirow{2}{*}{$\begin{array}{l}\text { average } \\
\text { age (y) }\end{array}$} & $\begin{array}{l}\text { Study } \\
\text { Design }\end{array}$ & $\begin{array}{l}\text { Study } \\
\text { Design }\end{array}$ & $\begin{array}{l}\text { Study } \\
\text { Design }\end{array}$ & $\begin{array}{l}\text { Study } \\
\text { Design }\end{array}$ & $\begin{array}{l}\text { Study } \\
\text { Design }\end{array}$ & \\
\hline & & & & \multicolumn{6}{|c|}{ CharacteristiđSharacteristiđSharacteristiđSharacteristiđSharacteristicA } \\
\hline & Control & HMB & & gender & $\begin{array}{l}\text { Duration } \\
(\mathrm{w})\end{array}$ & $\begin{array}{l}\text { HMB dose } \\
(\mathrm{gr})\end{array}$ & country & design & \\
\hline $\mathrm{C}, \mathrm{T}$ & 42 & 42 & 22.8 & M & 12 & 3 & Poland & $\mathrm{C}-\mathrm{O}$ & $\mathrm{D}$ \\
\hline $\mathrm{C}, \mathrm{T}$ & 8 & 8 & 21.4 & M & 6 & 3 & Iran & $\mathrm{P}$ & $\mathrm{A}$ \\
\hline $\mathrm{C}, \mathrm{T}$ & 16 & 16 & 19.5 & M & 12 & 3 & Poland & $\mathrm{C}-\mathrm{O}$ & $\mathrm{D}$ \\
\hline $\mathrm{C}, \mathrm{T}$ & 14 & 14 & 16.1 & $M \& F$ & 7 & 3 & Israel & $\mathrm{P}$ & $\mathrm{P}$ \\
\hline $\mathrm{C}, \mathrm{T}$ & 15 & 15 & 20.7 & M & 1.5 & 3 & USA & $\mathrm{P}$ & $\mathrm{H}$ \\
\hline $\mathrm{C}, \mathrm{T}$ & 5 & 11 & 24.9 & M & 6 & 3 & Australia & $\mathrm{P}$ & $\mathrm{C}$ \\
\hline $\mathrm{C}, \mathrm{T}$ & 7 & 7 & 24.6 & M & 6 & $\begin{array}{l}3 \\
\text { (Standard) }\end{array}$ & Australia & $\mathrm{P}$ & $\begin{array}{l}\mathrm{Sl} \\
\text { et }\end{array}$ \\
\hline $\mathrm{C}, \mathrm{T}$ & 7 & 8 & 24.6 & M & 6 & $\begin{array}{l}3 \\
\text { (Time } \\
\text { Releasing) }\end{array}$ & Australia & $\mathrm{P}$ & $\begin{array}{l}\text { Sl } \\
\text { et } \\
(2\end{array}$ \\
\hline
\end{tabular}

C, Cortisol; T, Testosterone; HMB, $\beta$-hydroxy- $\beta$-methylbutyrate; P, Parallel; C-O, cross-over studies; M, men; F, Female; W, weeks; Y, years; t, trained; U, untrained

Table 2. Cochrane Risk of Bias Assessment

\begin{tabular}{|c|c|c|c|c|c|c|c|c|}
\hline Study & $\begin{array}{l}\text { Random } \\
\text { Sequence } \\
\text { Generation }\end{array}$ & $\begin{array}{l}\text { Allocation } \\
\text { concealment }\end{array}$ & $\begin{array}{l}\text { Blinding of } \\
\text { partici- } \\
\text { pants and } \\
\text { personnel }\end{array}$ & $\begin{array}{l}\text { Blinding of } \\
\text { outcome } \\
\text { assessment }\end{array}$ & $\begin{array}{l}\text { Incomplete } \\
\text { outcome } \\
\text { data }\end{array}$ & $\begin{array}{l}\text { Selective } \\
\text { outcome } \\
\text { reporting }\end{array}$ & $\begin{array}{l}\text { Other } \\
\text { sources of } \\
\text { bias }\end{array}$ & $\begin{array}{l}\text { Overal } \\
\text { Risk of } \\
\text { Bias }\end{array}$ \\
\hline $\begin{array}{l}\text { Durkalec- } \\
\text { Michalski } \\
\text { et } \\
\text { al.(2017) }\end{array}$ & $\mathrm{L}$ & $\mathrm{L}$ & $\mathrm{L}$ & $\mathrm{L}$ & $\mathrm{L}$ & $\mathrm{L}$ & $\mathrm{L}$ & $\mathrm{L}$ \\
\hline $\begin{array}{l}\text { Asadi et } \\
\text { al. } \\
(2017)\end{array}$ & $\mathrm{L}$ & $\mathrm{H}$ & $\mathrm{L}$ & $\mathrm{L}$ & $\mathrm{L}$ & $\mathrm{L}$ & $\mathrm{L}$ & $\mathrm{L}$ \\
\hline
\end{tabular}




\begin{tabular}{|c|c|c|c|c|c|c|c|c|}
\hline Study & $\begin{array}{l}\text { Random } \\
\text { Sequence } \\
\text { Generation }\end{array}$ & $\begin{array}{l}\text { Allocation } \\
\text { concealment }\end{array}$ & $\begin{array}{l}\text { Blinding of } \\
\text { partici- } \\
\text { pants and } \\
\text { personnel }\end{array}$ & $\begin{array}{l}\text { Blinding of } \\
\text { outcome } \\
\text { assessment }\end{array}$ & $\begin{array}{l}\text { Incomplete } \\
\text { outcome } \\
\text { data }\end{array}$ & $\begin{array}{l}\text { Selective } \\
\text { outcome } \\
\text { reporting }\end{array}$ & $\begin{array}{l}\text { Other } \\
\text { sources of } \\
\text { bias }\end{array}$ & $\begin{array}{l}\text { Overall } \\
\text { Risk of } \\
\text { Bias }\end{array}$ \\
\hline $\begin{array}{l}\text { Durkalec- } \\
\text { Michalski } \\
\text { et al. } \\
(2015)\end{array}$ & $\mathrm{H}$ & $\mathrm{L}$ & $\mathrm{L}$ & $\mathrm{L}$ & $\mathrm{L}$ & $\mathrm{L}$ & $\mathrm{L}$ & $\mathrm{L}$ \\
\hline $\begin{array}{l}\text { Portal } \\
\text { et al. } \\
(2011)\end{array}$ & $\mathrm{L}$ & $\mathrm{L}$ & $\mathrm{L}$ & $\mathrm{L}$ & $\mathrm{L}$ & $\mathrm{L}$ & $\mathrm{U}$ & $\mathrm{L}$ \\
\hline $\begin{array}{l}\text { Hoffman } \\
\text { et al. } \\
(2004)\end{array}$ & $\mathrm{U}$ & $\mathrm{U}$ & $\mathrm{L}$ & $\mathrm{L}$ & $\mathrm{L}$ & $\mathrm{L}$ & $\mathrm{L}$ & $\mathrm{L}$ \\
\hline $\begin{array}{l}\text { Crowe } \\
\text { et al. } \\
(2003)\end{array}$ & $\mathrm{U}$ & $\mathrm{H}$ & $\mathrm{H}$ & $\mathrm{H}$ & $\mathrm{H}$ & $\mathrm{L}$ & L & $\mathrm{H}$ \\
\hline $\begin{array}{l}\text { Slater et } \\
\text { al. } \\
(2001)\end{array}$ & $\mathrm{U}$ & $\mathrm{L}$ & $\mathrm{U}$ & $\mathrm{U}$ & $\mathrm{U}$ & $\mathrm{L}$ & $\mathrm{L}$ & $\mathrm{M}$ \\
\hline
\end{tabular}

$\mathrm{L}$, low risk of bias; $\mathrm{H}$, high risk of bias; $\mathrm{M}$, medium risk of bias; $\mathrm{U}$, unclear risk of bias.

Table 3. Effect of HMB supplementation on cortisol concentration in athletes, subgroup analyses based on study duration and type of exercise activities (all analyses were conducted using random effects model).

\begin{tabular}{|c|c|c|c|c|c|c|c|}
\hline & & $\begin{array}{l}\text { Meta- } \\
\text { analysis }\end{array}$ & $\begin{array}{l}\text { Meta- } \\
\text { analysis }\end{array}$ & \multicolumn{4}{|c|}{ HeterogeneityHeterogeneityHeterogeneityHeterogenei } \\
\hline $\begin{array}{l}\text { Study } \\
\text { group }\end{array}$ & $\begin{array}{l}\text { No. of } \\
\text { effect sizes }\end{array}$ & $\begin{array}{l}\text { Effect } \\
\text { Mean } \\
\text { difference } \\
(95 \% \mathrm{CI})\end{array}$ & $P$ effect & $Q$ statistic & $\begin{array}{l}P \text { within } \\
\text { group }\end{array}$ & $I^{2}(\%)$ & $\begin{array}{l}P \text { between } \\
\text { group }\end{array}$ \\
\hline Duration & Duration & Duration & Duration & Duration & Duration & Duration & Duration \\
\hline$>6$ weeks & 3 & $\begin{array}{l}-0.25 \\
(-1.42 \\
0.90)\end{array}$ & 0.668 & 0.23 & 0.893 & 0.00 & 0.144 \\
\hline $\begin{array}{l}{[?] 6} \\
\text { weeks }\end{array}$ & 5 & $\begin{array}{l}-2.47 \\
(-4.72 \\
-0.21)\end{array}$ & 0.032 & 10.96 & 0.027 & 63.50 & \\
\hline $\begin{array}{l}\text { Type of } \\
\text { exercise }\end{array}$ & $\begin{array}{l}\text { Type of } \\
\text { exercise }\end{array}$ & $\begin{array}{l}\text { Type of } \\
\text { exercise }\end{array}$ & $\begin{array}{l}\text { Type of } \\
\text { exercise }\end{array}$ & $\begin{array}{l}\text { Type of } \\
\text { exercise }\end{array}$ & $\begin{array}{l}\text { Type of } \\
\text { exercise }\end{array}$ & $\begin{array}{l}\text { Type of } \\
\text { exercise }\end{array}$ & $\begin{array}{l}\text { Type of } \\
\text { exercise }\end{array}$ \\
\hline activities & activities & activities & activities & activities & activities & activities & activities \\
\hline $\begin{array}{l}\text { Aerobic } \\
\text { and } \\
\text { anaerobic } \\
\text { combined }\end{array}$ & 4 & $\begin{array}{l}-0.16 \\
(-1.16 \\
0.84)\end{array}$ & 0.753 & 0.32 & 0.956 & 0.00 & 0.003 \\
\hline $\begin{array}{l}\text { Resistance } \\
\text { training }\end{array}$ & 4 & $\begin{array}{l}-3.30 \\
(-5.50 \\
-1.10)\end{array}$ & 0.003 & 4.93 & 0.177 & 39.1 & \\
\hline
\end{tabular}




\begin{tabular}{|c|c|c|c|c|c|c|c|}
\hline \multirow[b]{2}{*}{ Overall } & \multirow[b]{2}{*}{8} & \multirow{2}{*}{$\begin{array}{l}\begin{array}{l}\text { Meta- } \\
\text { analysis }\end{array} \\
-1.35 \\
(-2.70 \\
0.002)\end{array}$} & \multirow{2}{*}{$\begin{array}{l}\text { Meta- } \\
\text { analysis }\end{array}$} & \multicolumn{4}{|c|}{ HeterogeneityHeterogeneityHeterogeneityHeterogenei } \\
\hline & & & & 14.05 & 0.050 & 50.20 & - \\
\hline
\end{tabular}

Table 4. Effect of HMB supplementation on testosteron concentration in athletes, subgroup analyses based on study duration and type of exercise activities (all analyses were conducted using random effects model).

\begin{tabular}{|c|c|c|c|c|c|c|c|}
\hline & & $\begin{array}{l}\text { Meta- } \\
\text { analysis }\end{array}$ & $\begin{array}{l}\text { Meta- } \\
\text { analysis }\end{array}$ & \multicolumn{4}{|c|}{ HeterogeneityHeterogeneityHeterogeneityHeterogenei } \\
\hline $\begin{array}{l}\text { Study } \\
\text { group }\end{array}$ & $\begin{array}{l}\text { No. of } \\
\text { effect sizes }\end{array}$ & $\begin{array}{l}\text { Effect } \\
\text { Mean } \\
\text { difference } \\
(95 \% \mathrm{CI})\end{array}$ & $P$ effect & $Q$ statistic & $\begin{array}{l}P \text { within } \\
\text { group }\end{array}$ & $I^{2}(\%)$ & $\begin{array}{l}P \text { between } \\
\text { group }\end{array}$ \\
\hline Duration & Duration & Duration & Duration & Duration & Duration & Duration & Duration \\
\hline$>6$ weeks & 3 & $\begin{array}{l}1.60(0.08, \\
3.12)\end{array}$ & 0.039 & 0.28 & 0.870 & 0.00 & 0.188 \\
\hline $\begin{array}{l}{[?] 6} \\
\text { weeks }\end{array}$ & 5 & $\begin{array}{l}0.38 \\
(-0.62 \\
1.38)\end{array}$ & 0.455 & 1.32 & 0.858 & 0.00 & \\
\hline $\begin{array}{l}\text { Type of } \\
\text { exercise } \\
\text { activities }\end{array}$ & $\begin{array}{l}\text { Type of } \\
\text { exercise } \\
\text { activities }\end{array}$ & $\begin{array}{l}\text { Type of } \\
\text { exercise } \\
\text { activities }\end{array}$ & $\begin{array}{l}\text { Type of } \\
\text { exercise } \\
\text { activities }\end{array}$ & $\begin{array}{l}\text { Type of } \\
\text { exercise } \\
\text { activities }\end{array}$ & $\begin{array}{l}\text { Type of } \\
\text { exercise } \\
\text { activities }\end{array}$ & $\begin{array}{l}\text { Type of } \\
\text { exercise } \\
\text { activities }\end{array}$ & $\begin{array}{l}\text { Type of } \\
\text { exercise } \\
\text { activities }\end{array}$ \\
\hline $\begin{array}{l}\text { aaaAerobic } \\
\text { and } \\
\text { anaerobic } \\
\text { combined }\end{array}$ & 4 & $\begin{array}{l}1.56(0.07 \\
3.05)\end{array}$ & 0.040 & 0.34 & 0.952 & 0.00 & 0.196 \\
\hline $\begin{array}{l}\text { Resistance } \\
\text { training }\end{array}$ & 4 & $\begin{array}{l}0.38 \\
(-0.63, \\
1.38)\end{array}$ & 0.464 & 1.32 & 0.725 & 0.00 & \\
\hline Overall & 8 & $\begin{array}{l}0.75 \\
(-0.09, \\
1.58)\end{array}$ & 0.079 & 3.33 & 0.853 & 0.00 & - \\
\hline
\end{tabular}

